Journalof BANKING \&

FINANCE

\title{
Lending relationships in Germany - Empirical evidence from survey data
}

\author{
Dietmar Harhoff ${ }^{a, b, c}$, Timm Körting ${ }^{\text {b,* }}$ \\ a Wissenschaftszentrum Berlin (WZB), Reichpietschufer 50, 10785 Berlin, Germany \\ ${ }^{\mathrm{b}}$ Zentrum für Europäische Wirtschaftsforschung (ZEW), Postfach 103443, 68034 M annheim, \\ Germany \\ ${ }^{c}$ Centre for Economic Policy Research (CEPR), 90-98 Goswell Road, London ECIV 7OB, UK
}

\begin{abstract}
We examine empirically the role of lending relationships in determining the costs and collateral requirements for external funds. The data originate from a recently concluded survey of small and medium-sized German firms. In our descriptive analysis, we explore the borrowing patterns and the concentration of borrowing from financial institutions. Using data on L/C interest rates, collateral requirements, and the firm's use of fast payment discounts we find that relationship variables may have some bearing on the price of external funds, but much more so on loan collateralization and availability. Firms in financial distress face comparatively high $\mathrm{L} / \mathrm{C}$ interest rates and reduced credit availability. (c) 1998 Elsevier Science B.V. All rights reserved.
\end{abstract}

J EL classification: G21; D45

Keywords: Lending relationships; Credit rationing; Financial intermediation

\section{Introduction}

The relationships between firms and external financiers can be affected by a number of problems. Due to incompleteness of contracts and the intertemporal

\footnotetext{
*Corresponding author. Tel.: 49621 1235 145; fax: 49621 1235 223;; e-mail: koerting@zew.de 
structure of lending transactions, hold-up problems may arise. If the respective partners cannot commit ex ante to non-opportunistic behavior, the investment and funding decisions may not be fully efficient. Furthermore, in the presence of asymmetric information, adverse selection and moral hazard may lead investors to ration credit.

A growing literature addresses these problems and the extent to which they may be reduced by implicit contracts. The relationships between banks and enterprises have become particularly relevant in this discussion. Long-term relationships between banks and firms may be an important instrument for counteracting informational asymmetries, which are presumably characteristic of financial markets and the likely cause of financing constraints. Developing a reputation for non-opportunistic behavior in such a relationship may be important for solving commitment problems. Presumably, the above-mentioned problems (and the need for solving them) are particularly pronounced for smaller firms which face idiosyncratic risks and relatively high volatility in their economic environment. ${ }^{2}$ Prior studies, e.g. by Petersen and Rajan (1994) and Berger and Udell (1995), have shown that the quality of bank-firm lending relationships is an important determinant for financing conditions of SMEs in the United States. To date, no comprehensive study of this kind has been undertaken for German SMEs, although the German economy has been singled out by some observers as the archetypical case of a bank-based financial system (Allen and Gale, 1995). Moreover, German banks have often been praised as being particularly effective in channelling investment funds to SMEs. One might therefore expect that the quality of lending relationships should be of particular importance in this country.

In this paper, we present a study of lending relationships between banks and SMEs in the German economy. Our contribution to the literature is twofold. First, based on new survey data we provide large-sample descriptive evidence on the nature of lending relationships for German SMEs, and in particular on the concentration of borrowing and the degree of exclusivity in bank-firm lending relationships. Such evidence has not been produced prior to this study,

\footnotetext{
${ }^{1}$ The potential impact of credit rationing on the firm's investment policy has been addressed in a large number of empirical studies. See Schiantarelli (1995) for a survey and discussion. Some of these studies have been criticized for using inconclusive tests. For a detailed critique see Kaplan and Zingales (1997). Yet, even critics of these studies do not question that financing constraints are likely to exist.

${ }^{2}$ For a country like Germany it should be particularly important to analyze the financing of small and medium-sized enterprises (SMEs), since these firms account for a relatively large share of employment and output. According to the 1987 Census of Establishments $78.6 \%$ of establishments and $65.4 \%$ of all firms in the non-agricultural private sector had fewer than 500 employees. Loveman and Sengenberger (1991) show that these shares are quite high in comparison to those in UK and the US.
} 
and the issue has been controversial. ${ }^{3}$ Second, we contribute a multivariate analysis of the determinants of collateral requirements, L/C interest rates, and the availability of external finance (measured by fast payment discounts taken). Naturally, variables that are supposed to describe the quality of lending relationships are particularly important in this exercise. We employ a number of such indicators: the duration of the lending relationship, the number of financial institutions the firm is actually borrowing from, and a subjective response in which firm managers indicate to which extent they consider their bank relationship as being characterized by mutual trust.

Our descriptive evidence suggests a high degree of concentration in borrowing. While the concentration of borrowing decreases strongly with firm size, even the largest firms in our sample receive about two-thirds of the total credit volume from one institution. A substantial fraction of firms even maintains exclusive lending relationships: about $50 \%$ of all firms with fewer than 10 employees receive their external finance from one institution only. Further descriptive results are provided below. In our multivariate specifications, we find that the incidence of collateralization of the firm's most important line of credit decreases with the duration of the lending relationship and increases with the number of institutions the firm is borrowing from. The result can be obtained irrespective of the inclusion of the trust variable which is potentially endogenous, but yields a negative and highly significant coefficient in our collateral equation. As to $\mathrm{L} / \mathrm{C}$ interest rates, neither the duration variable nor the number of lenders have any explanatory power for the cost of credit. The coefficient of the trust variable is again highly significant and negative, indicating that the other two variables may not be sufficient to characterize lending relationships well. Firms which have been in financial distress during the past five years face comparatively unfavorable financing conditions, both in terms of collateral as well as interest rates. In essence, we find that firms with more concentrated borrowing and long-lasting bank relationships fare better than other enterprises in terms of collateral requirements, interest rates, and credit availability. Other effects are discussed in detail below.

In the remainder of this paper, we start by discussing central theoretical and conceptual issues in Section 2. We also discuss some of the existing empirical evidence. In Section 3, we then briefly describe the data set used in our analysis.

\footnotetext{
${ }^{3}$ See for example the discussion in Edwards and Fischer (1994). In a parallel work, Jan Pieter Krahnen, Martin Weber and their associates have collected panel data from credit files of five large German banks. See Elsas et al. (1997) for a description of their data which is uniquely suited to study the dynamics of lending relationships between banks and firms. However, their sample contains only a few firms with sales of less than DM 50 million (1996). Conversely, in our 1997 sample only $6 \%$ of the firms have sales of morethan DM 50 million. Moreover, the data collected in our project can be used to compute "representative" statistics for the overall SME sector in Germany.
} 
The interested reader may consult the data appendix in which sampling and interview procedures are described in more detail. Based on our theoretical discussion and the data at hand, we then consider in turn the following empirical issues:

- the patterns of borrowing and the extent of lending concentration in German SMEs,

- the incidence of collateral requirements for bank lines of credit (L/Cs),

- the cost of external finance (measured by L/C interest rates),

- and the availability of external finance.

We comment on our results and on further research in the concluding section.

\section{Theoretical foundations and prior empirical evidence}

\subsection{Theoretical issues}

The interaction between borrowers and lenders has been considered in the theoretical literature from a number of perspectives. Financial markets appear to behave differently from standard goods exchanges in that prices do not necessarily adjust such as to allow for market-clearing. In business surveys, firms frequently allude to the lack of equity and/or external finance as a major impediment to enlarging their investment and innovation activities. Such survey responses may indicate the presence of rationing phenomena which can be analyzed in a number of theoretical frameworks, e.g. as problems of moral hazard and adverse selection (Stiglitz and Weiss, 1981), of costly state-verification (Gale and Hellwig, 1985; Mokerjee and Png, 1989), or in the context of incomplete contracting (Aghion and Bolton, 1992). An important feature of the literature is the result that collateralization may under some circumstances be conducive to overcoming credit rationing problems (Bester, 1985). ${ }^{4}$ Surveys of these models and their implications have been presented by Bhattacharya and Thakor (1993) and by Van Damme (1994). We restrict ourselves here to a discussion of theoretical contributions which are most relevant for our study.

Many of the papers in this area can be traced back to some thought-provoking ideas put forth by Mayer (1988). Mayer questions the conventional view that unbridled competition among suppliers of finance will improve credit availability as well as price conditions (i.e. interest rates), as one would expect in standard commodity markets. In Mayer's view, competitive banking markets may perform badly, since banks are barred from committing themselves to the rescue or the funding of a firm's long-term investment. The bank that provides the lion share of the firm's external finance and which maintains a

\footnotetext{
${ }^{4}$ See Schmidt-Mohr (1997) for a discussion and generalization of some of the results.
} 
long-term, though not necessarily exclusive lending relationship is often referred to as a house bank. ${ }^{5}$ It has been suggested that the house bank phenomenon is particularly widespread in Germany, and this suggestion, though controversial, has caught the attention of a number of researchers. We briefly summarize a number of theoretical models that focus on the costs and benefits of long-term lending relationships.

Based on Mayer (1988), Fischer (1990) describes two types of dynamic inconsistency problems related to the formation of close lending relationships. If a firm has to finance a long-term project from external sources, the project may initially produce negative returns, but these are compensated by high positive returns later on. Ex ante contracting over the full duration of the project may not be feasible, and therefore some recontracting may take place during the project's duration. At this point, the firm may be vulnerable to opportunistic behavior on part of the bank, e.g. if the latter demands higher interest rates for the second period. The expectation of such opportunistic behavior could lead the firm to abstain from undertaking the project altogether. Both the bank and the firm would prefer if the bank could commit to non-opportunistic behavior. A similar problem may emerge on the side of borrowers. Firms in financial distress may be in need of a bank-led "rescue operation". But engaging in the reorganization, the bank may incur losses in the short run, since the firm is not capable of assuming a higher debt or interest burden. If the firm cannot commit itself to a long-term lending relationship which would allow the bank to compensate short-term losses in the long run, banks in competitive banking system will not undertake the rescue. However, competition can be restricted if bank and firm engage in a long-term relationship which gives the 'house bank' an informational advantage and thus some ex post monopoly power.

Greenbaum et al. (1989) and Sharpe (1990) provide similar models in which long-term relationships between banks and firms may emerge endogenously. As in Fischer (1990), these models predict that the bank will develop informational monopoly power over 'high quality' firms. Since banks earn rents on these relationships and since competition drives overall profits to zero in these models, the banks charge relatively low interest rates to borrowers of unknown quality, but then exploit the emerging informational

\footnotetext{
${ }^{5}$ It is difficult to give a precise definition of what constitutes a 'house bank.' Fischer (1990), pp. 3-4, argues that house banks can be characterized w.r.t. four features. First, they account for the largest share of external finance. Moreover, they tend to provide the largest share of financial services in general. Second, house banks entertain long-term relationships with their customers. These relationships are characterized by considerable trust between the partners. Third, their role as the dominant lender and the preferred access to information give house banks an influential role. Fourth, house banks will play an important role when the firm faces a period of financial distress or the need of restructuring.
} 
monopoly. ${ }^{6}$ Thus, firms of high quality do not experience an improvement in their financing conditions, since they cannot convey information about their quality to other banks. Their low risk of default is therefore not reflected in the interest rate and other non-price terms.

A contrasting view is provided by Petersen and Rajan (1995) and by Boot and Thakor (1994). Petersen and Rajan (1995) demonstrate that banks may have an incentive to charge high interest rates early on (reflecting the expectation that some firms are "bad risks") and that financing conditions for those firms which turn out to be "good risks" improve over time. Boot and Thakor (1994) model an infinitely repeated game between lenders and borrowers. Collateralization of loans is explicitly taken into account in their model. The qualitative predictions are similar to those of the Petersen/Rajan model: firms will pay relatively high interest early in the bank-firm relationships. Later, after providing proof that investment projects have been concluded successfully, the lender will pledge no collateral anymore and will also enjoy improved price conditions.

These theoretical models typically distinguish between firms (or investment projects) in terms of their quality. The underlying quality is modelled as a timeinvariant characteristic. While cases of financial distress are not modelled explicitly, one is tempted to conclude that such events may lead the bank to reevaluate the firm's quality. Subsequently, credit conditions may deteriorate, both in price and non-price terms.

\subsection{Previous empirical results ${ }^{7}$}

The dichotomy of Germany and Japan as bank-dominated financial systems, and of the UK and the US as market-based systems has dominated corporate finance folklore for some time. For the case of Germany, this view has been challenged only quite recently by Corbett and Jenkinson (1994) who show that Germany, the UK and the US do not differ with respect to the share of finance coming from banks. But even if corporate finance in Germany may not be particularly dependent on bank finance, Mayer's hypothesis that German banks are particularly effective in channelling long-term debt to firms in the non-financial sector may still hold (Mayer, 1988).

While Fischer (1990) presents a theoretical model illuminating the advantages of close lending relationships, he also provides some evidence that this model may not provide a good depiction of contemporary banking practices in

\footnotetext{
${ }^{6}$ Rajan (1992) developed a model where the firm anticipates the bank's ex-post monopoly power and therefore turns to market-provided debt finance. Market debt is not an option for the SMEs in our sample, and therefore we do not discuss this issue in more detail here.

${ }^{7}$ As in the theoretical discussion, we are discussing selected papers. More detailed summaries of previous work can be found in Petersen and Rajan (1994, 1995), Berger and Udell (1995) and Fischer (1990).
} 
Germany. ${ }^{8}$ Summarizing the results from 34 interviews with large banks and firms, Fischer suggests that commitment mechanisms have only little importance for bank finance in Germany. He notes that competition appears to be well at work in that market shares of individual banks are quite low, and that due to competition, banks have little discretion over interest rates. Intertemporal compensation is thus made impossible. Moreover, he argues that firms in good standing ('high quality' firms) tend to maintain multiple banking relationships, and that banks prefer to share risks with other banks. The arguments collected by Edwards and Fischer (1994) extend this line of thought. Not only is there little evidence of high banking concentration and exclusive firm-bank relationships in Germany, but firms seeking such a relationship are even characterized as the financially weaker and less profitable SMEs (see Edwards and Fischer, 1994, p. 145). Edwards and Fischer also dispute that banks have significant influence on the policies of these firms - either through supervisory board seats or through proxy votes in shareholder meetings. It should be emphasized, however, that most of the Edwards/Fischer study analyzes the role of banks in the governance of large publicly traded enterprises. There is virtually no evidence with respect to small and medium-sized firms. Thus, their study in conjunction with the earlier results reported by Fischer (1990) leave open whether there are segments of small and medium-sized firms in the German economy for which close banking relationships have positive effects. This is in essence one of the questions we seek to answer in this paper.

Two other papers studying firm-bank relationships in the US are of particular relevance to our analysis. Petersen and Rajan (1994) use data from a detailed survey administered by the US Small Business Administration (SBA). As a result of this data collection effort, they are able to analyze the financing of about 3400 US enterprises with fewer than 500 employees. The survey data include information on loan conditions (interest rates, maturity, collateral) and on other sources of funds such as trade credit, equity finance, leasing contracts, etc. Moreover, the data contain information on lending relationships, i.e. on the duration of bank-firm relationships, the number of financial institutions a firm is relying on, and the share of total bank funding coming from the particular lender. Petersen and Rajan (1994) analyze the data with respect to interest rates and loan availability, using firm characteristics like size and age and characteristics of lending relationships as exogenous regressors. To separate groups of firms according to financing constraints, they use the extent of trade credit as an indicator. Since trade credit is presumably the most expensive external source of finance (Elliehausen and Wolken, 1993), this is a reasonable proxy variable for a debt-constrained financial regime in small companies.

\footnotetext{
${ }^{8}$ For earlier studies on collateralization of bank loans and bank behavior during financial distress see Drukarcyk et al. (1985) and Hesselmann and Stefan (1990).
} 
They find that the extent of trade credit usage is negatively related to the age of the enterprise and the duration of existing lending relationships.

Berger and Udell (1995), using the same dataset as Petersen and Rajan (1994), concentrate on collateral requirements and interest rates for lines of credit (L/Cs). These authors argue that a study of L/Cs should be particularly revealing, since relationships are more likely to matter in this context than for mortgages or other types of loans. They also note that the interest rate regressions in Petersen and Rajan (1994) combine various types of loans in one equation, and that focussing on one particular type of loan may yield cleaner results. Berger and Udell find that firms with longer lending relationships have to pledge collateral less frequently, and that interest on L/Cs decreases as a function of duration. Thus, contrary to the results reported by Petersen and Rajan (1994), the duration of a lending relationship may after all have some impact on credit price terms.

Taken together, these studies provide fairly strong support that the quality of lending relationships improves the availability of bank loans and - in the case of L/C interest rates in the US as studied by Berger and Udell - also affect price conditions significantly. Moreover, it seems that enhanced competition between financial institutions (as measured by the number of institutions the firm borrows from) will lead to a reduction in the availability of loans. However, note that this result is not supported by the interview data described in Edwards and Fischer (1994) for the case of the German banking system. Note finally that the empirical studies at hand appear to agree on the role of firm age and firm size. Relatively small firms and relatively young firms may have greater difficulties in obtaining funds than their larger and older counterparts. ${ }^{9}$ One would expect that this finding should not vary across countries, while the incidence and impact of long-term lending relationships need not be similar. After all, the institutional setups of the respective financial sectors are quite different. A study of lending relationships in the country where these have been assumed to play a major role should therefore be a worthwhile endeavor.

\section{Hypotheses and empirical analysis}

\subsection{Hypotheses}

Based on the theoretical arguments and previous empirical evidence, we summarize here our central hypotheses.

\footnotetext{
${ }^{9}$ Harhoff (1998) finds in a sample of medium-sized and large firms that liquidity effects are present only in the lower tercile of the size distribution. Subjective responses from survey data support that conclusion. Winker (1996) also provides evidence that smaller firms are more affected by lack of equity and debt finance than larger firms.
} 
- H1. As the lending relationship continues, price and non-price credit conditions will not improve or even deteriorate due to the emergence of an informational monopoly.

- H2. Firms with long-lasting lending relationships and/or concentrated borrowing patterns will incur lower costs of capital, and/or will have better access to external finance, including lower collateral requirements.

These hypotheses summarize the contradictory predictions from the models described above. H1 is consistent with the work of Fischer (1990), Sharpe (1990), and Greenbaum et al. (1989). H2 summarizes the predictions from the Petersen and Rajan (1994) and Boot and Thakor (1994) models, which obviously contradict hypothesis $\mathrm{H} 1$. We complement these competing hypotheses with a less controversial one on the relationship between firm age, firm size and cost and availability of credit. Firm size effects are likely to reflect the bargaining power of larger borrowers, while age effects should be present if the average quality of firms improves with age due to selection effects. Hence:

- H3. Availability of capital will increase with firm size and age, while the cost of capital and the incidence of collateralization will decrease in these variables.

In our empirical tests of these hypotheses, we combine elements of the two most extensive analyses on lending relationships in the US, i.e. the study by Petersen and Rajan (1994) and Berger and Udell (1995). We follow the example of the latter study by concentrating on collateral requirements and interest rates for lines of credit, while we also employ trade credit data as in Petersen/ Rajan in order to assess the impact of lending relationships on credit availability. The data and variables at hand are described in the following two subsections before we turn to the descriptive and the multivariate analysis.

\subsection{Data}

A detailed description of the data used in this study is presented in Appendix A. The database covers non-subsidiary firms from all major sectors of the German economy with no more than 500 employees.

There are a number of reasons for the exclusion of subsidiary firms, i.e. of enterprises in which other firms held $50 \%$ or more of the shares. As pointed out in Harhoff et al. (1998), liability of subsidiaries in the case of insolvency is typically passed on to the parent company. Indeed, prior interviews with banks suggest that banks almost always insist on a guarantee by the parent $(\mathrm{Pa}-$ tronatserklärung). The relatively low insolvency rate of subsidiaries is therefore not surprising - the preferred type of exit of these firms is a voluntary liquidation. The characteristics of the subsidiary firm may therefore carry no information about its creditworthiness. Moreover, the firm whose characteristics do matter for the subsidiary's creditworthiness is likely to be relatively large. 
As to industrial coverage, our sample deliberately encompasses firms from all sectors of the economy. We chose to include firms from the service, transportation and trade sectors since these account for a growing share of the economy. Moreover, some sectors in these industries may be subject to a lack of collateral precisely because production is less capital-intensive than in manufacturing.

The industrial composition of our sample is described in Table 1. The majority of firms $(44.5 \%)$ are in the manufacturing sector, but services, transportation and trade also account for $40.6 \%$. The remaining 209 firms (14.9\% of the sample) operate in the construction sector. The main characterizing variables for our firms are size (measured as average number of employees in 1996) and age (1997 minus the year in which the firm was officially registered at the Handelsregister, or if no entry in the Handelsregister was necessary, 1997 minus the start-up year taken from our survey). ${ }^{10}$ Since age and size distributions tend to be heavily skewed, the mean values of the sample are not particularly informative and the information on medians is more relevant. As one would expect given our sampling design the firms are quite small with median employment of 10 employees. The median age of all firms is 11 years, but firms in construction and services are on average considerably younger than manufacturing firms. Again this is an expected result, given that firm turnover in these sectors is particularly high (see Harhoff et al., 1998).

\subsection{Endogenous and explanatory variables}

Before turning to our descriptive and multivariate results, we briefly discuss the endogenous and explanatory variables used in the specifications described below. These are summarized in Table 2. To test our hypotheses, we employ three different multivariate specifications. First, we model the incidence of collateral requirements for the firm's most important line of credit. The dependent variable is set to one if some form of collateral or guarantee was required to obtain the $\mathrm{L} / \mathrm{C}$. The second specification is a model of the interest rate on the most important L/C. The reference day is 1 January 1997. Credit availability is not observable directly, and we follow the strategy employed by Petersen and Rajan (1994) who use the share of fast payment discounts actually taken as an indirect measure. Details of this measure are discussed below.

We have assigned the explanatory variables to four groups. Data on observable firm characteristics are used to reduce the impact of heterogeneity of

\footnotetext{
${ }^{10}$ We truncate the age distribution at 8 years for East German firms. The same rule applies to the duration of the relationships between the firm and its lending institutions. Our rationale for doing so is that banks will not base their evaluation of the firm's creditworthiness on information that was produced prior to the 1989 breakdown of the socialist East German regime.
} 


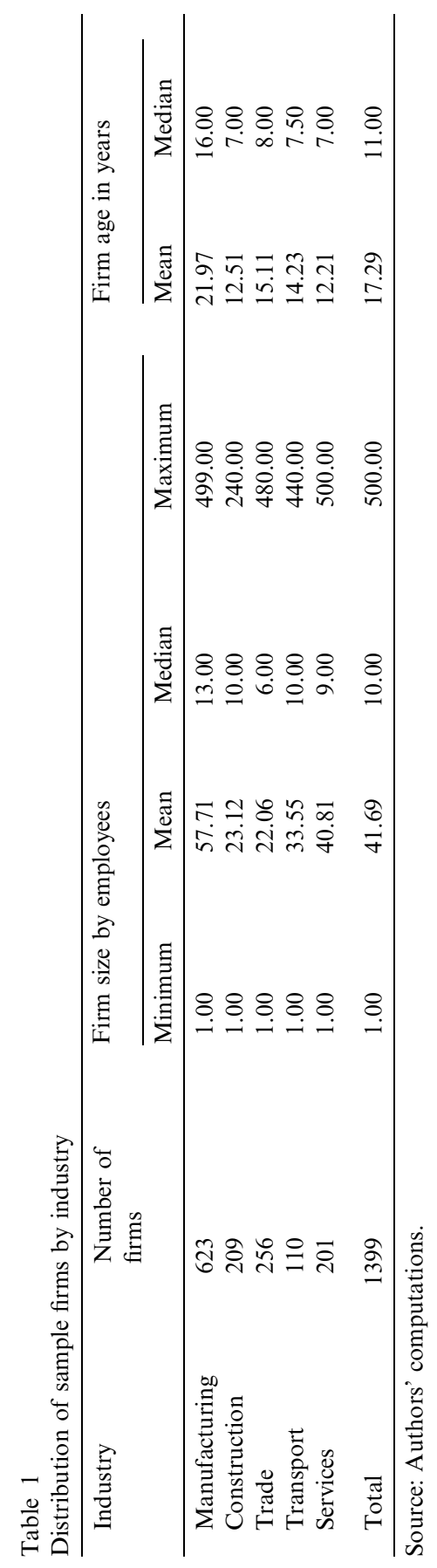




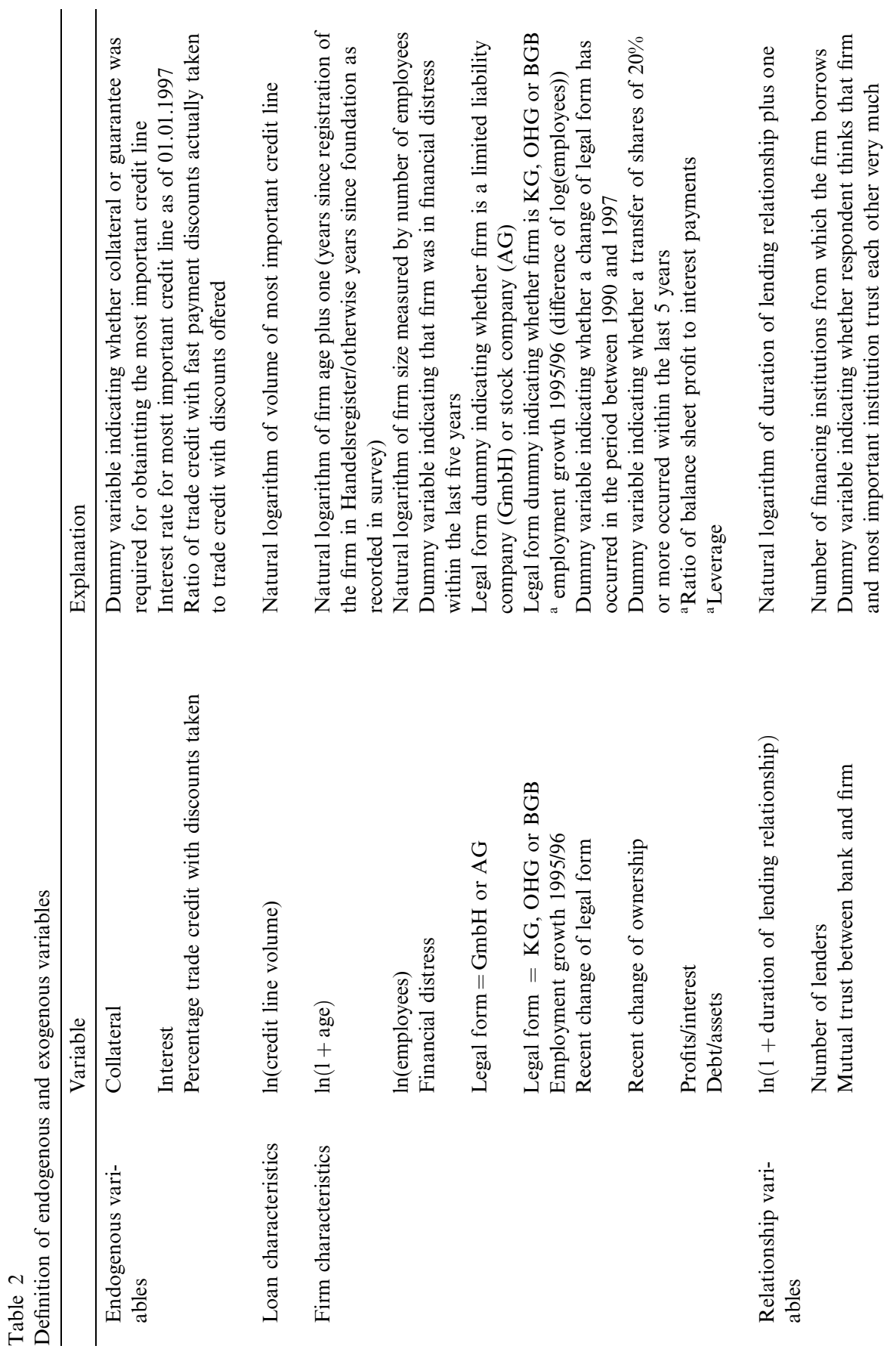



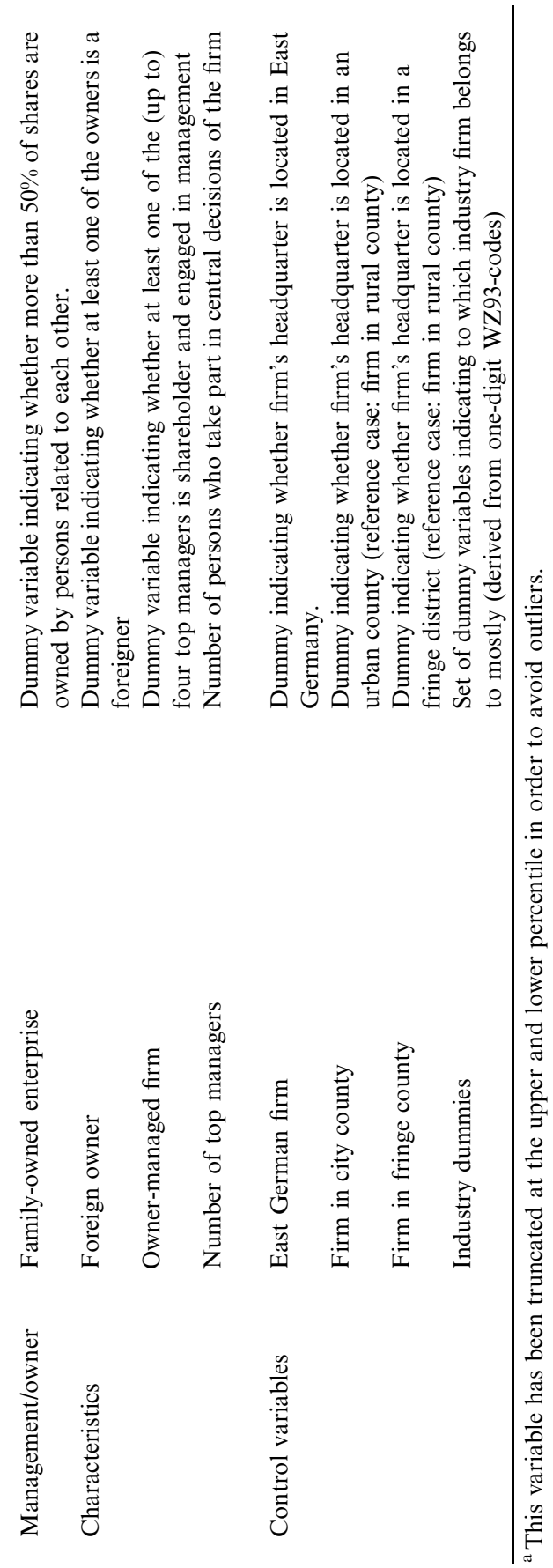
firms in our sample. In particular, we use the logarithm of age and size, indicator variables describing whether the firm experienced financial distress, legal form dummy variables, employment growth, dummy variables indicating a change in legal 


\subsection{Patterns of borrowing and lending concentration}

Table 4 summarizes the concentration of borrowing by firm age and size for the 1127 firms in our sample of 1399 firms which actually borrowed from financial institutions. Total borrowing of German SMEs typically comprised borrowing from financial institutions and borrowing from shareholders and/or family members or friends. In order to come up with a simple questionnaire item, the question upon which Table 4 is based asks for the share of borrowing from the most important five institutions.

Considering Panel A of Table 4, it is evident that borrowing by small firms is considerably more concentrated than borrowing by larger firms. For the group of firms with fewer than five employees, $80.1 \%$ of external funding come on average from one institution, while firms with $250-500$ employees borrow only $61.7 \%$ from the most important institution on average. The mean and median number of borrowing relationships increase with firm size. The share of funds borrowed from the five largest lenders taken together increases with firm size, reflecting the fact that borrowing from shareholders, family members and friends becomes less important as firms get larger. Panel B shows that similar results can be obtained with respect to firm age. Younger firms generally display more concentrated borrowing patterns than more seasoned firms. The number of different borrowing relationships increases considerably with firm age, but less strongly than with firm size.

Naturally, the simplest explanation of these patterns is one of fixed costs for maintaining a borrowing relationship. But besides differences on the cost side, the benefits of multiple banking relationships may also be size-contingent. Assuming that lenders prefer concentrated lending relationships in order to obtain informational advantages and that less concentrated borrowing structures may require a risk premium, small firms may not have the bargaining power to prevent a deterioration of credit conditions once they decide to use less concentrated borrowing patterns.

One may ask whether firms that employ concentrated borrowing structures differ in terms of observable characteristics from firms borrowing from a larger number of institutions. We attempt to provide a tentative answer in Table 5 which summarizes the mean values of important indicators for groups of firms with one, two or more than two lenders. We also report the $p$-value of simple ANOVA models which test for significant differences of the means across the three groups. Speaking in broad terms, there is no convincing evidence that firms with less concentrated borrowing (i.e. with a relatively large number of lenders) appear superior in terms of their indicator variables. If anything, the converse is the case. Equity ratio, return on sales and the trade credit variables suggest that firms with fewer lenders may be superior, ceteris paribus, although the relationship is often not significant. Nonetheless, there is no support for the Edwards/Fischer suggestion that it is mainly financially weak firms which want 


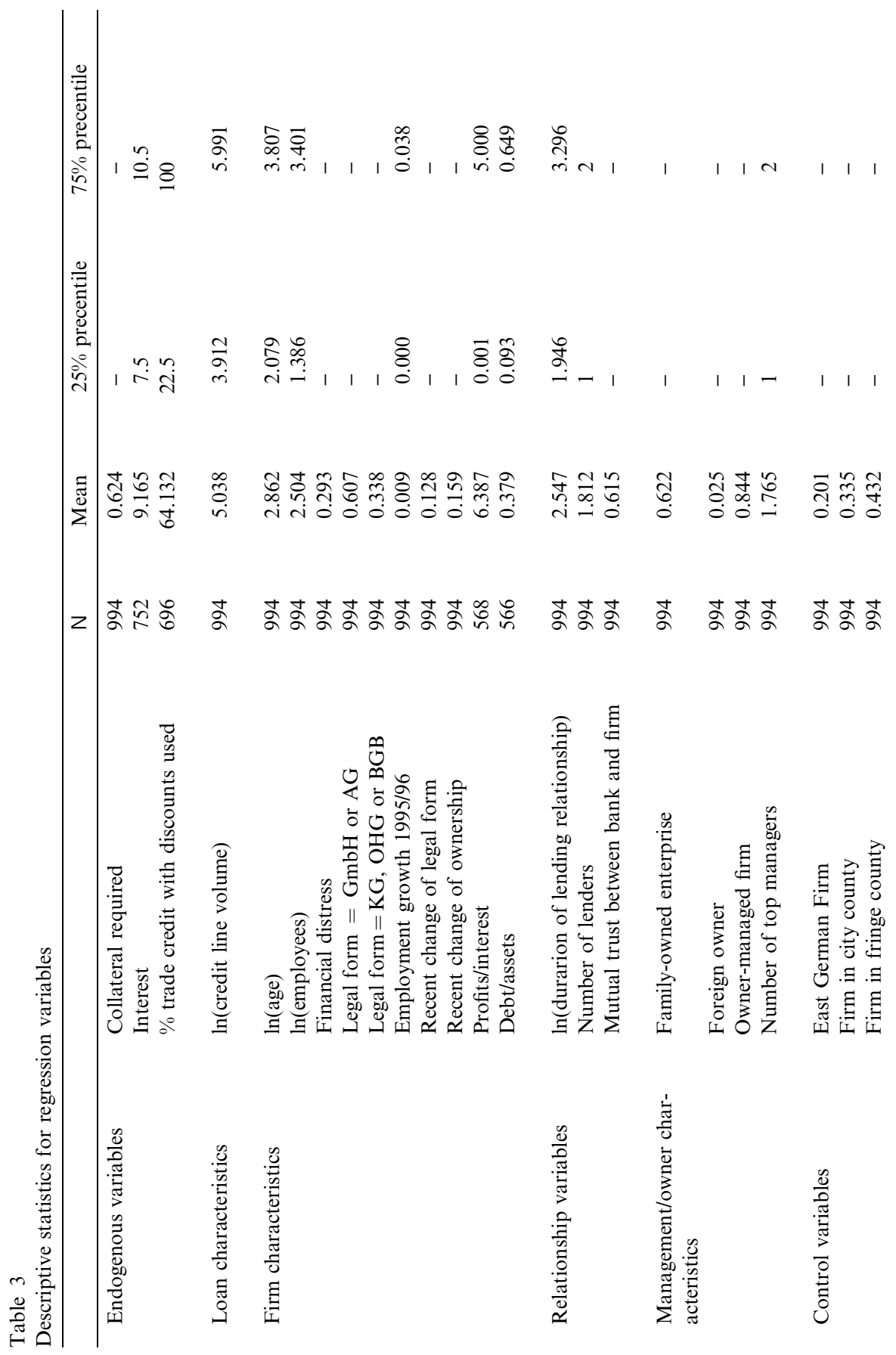


D. Harho , T. Körting / J ournal of Banking \& Finance 22 ( 1998) 1317-1353

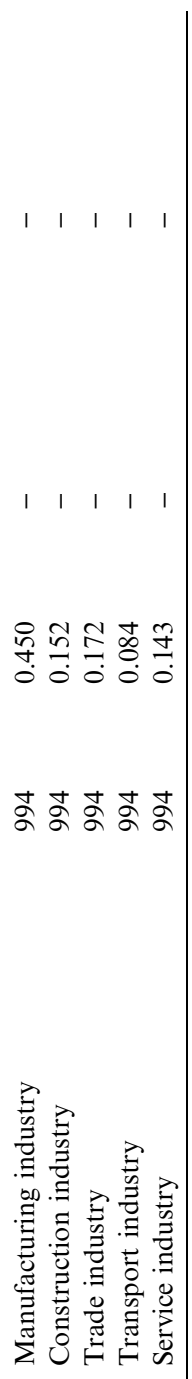




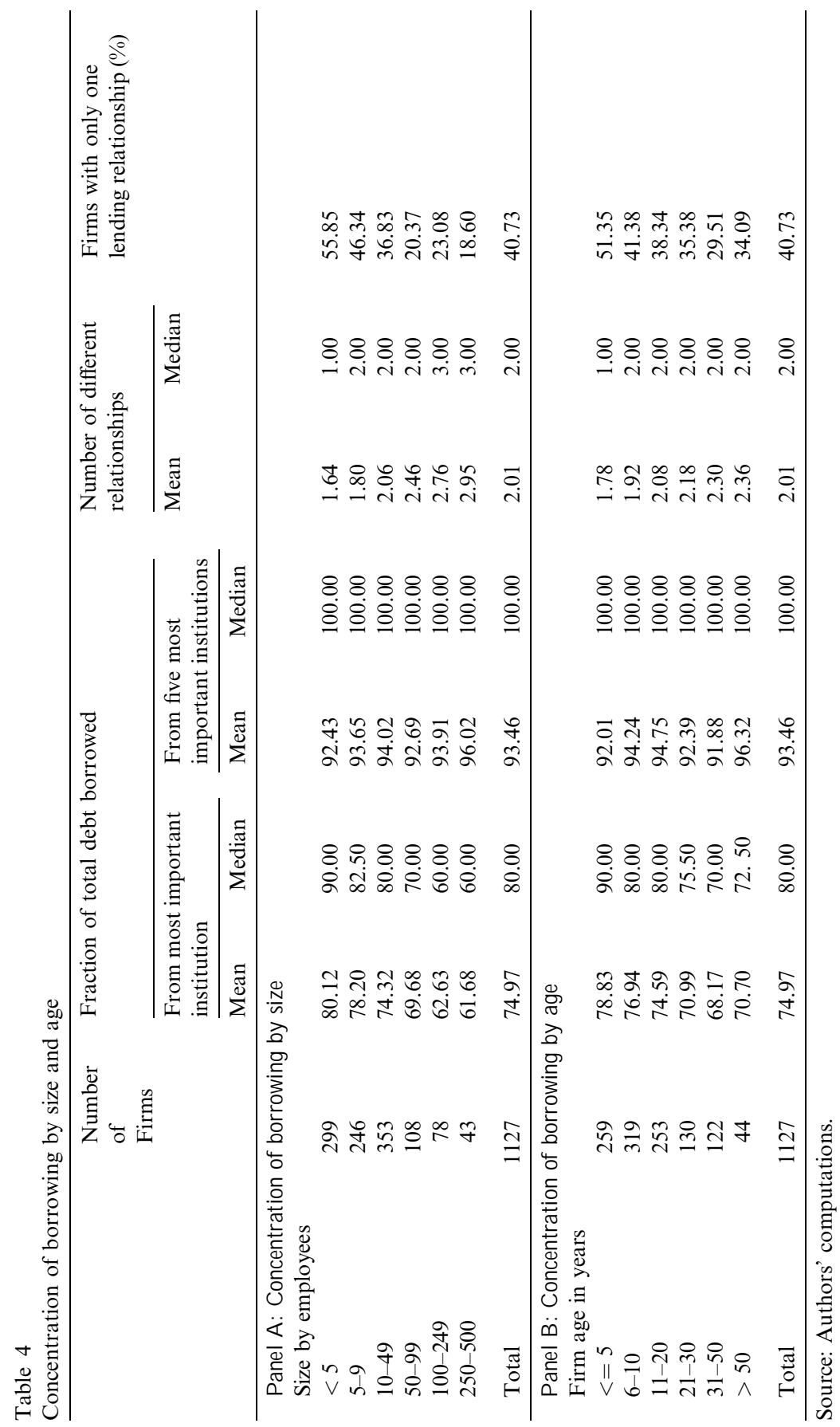


Table 5

Firm characteristics and lending relationships

\begin{tabular}{|c|c|c|c|c|c|}
\hline \multirow[t]{2}{*}{ Variables } & \multicolumn{3}{|c|}{$\begin{array}{l}\text { Means of variables by number } \\
\text { of lenders }\end{array}$} & \multirow[t]{2}{*}{ F-test } & \multirow[t]{2}{*}{ p-value } \\
\hline & $>2$ & 2 & 1 & & \\
\hline Equity ratio & $\begin{array}{l}0.201 \\
(181)\end{array}$ & $\begin{array}{l}0.199 \\
(169)\end{array}$ & $\begin{array}{l}0.230 \\
(316)\end{array}$ & 2.14 & 0.119 \\
\hline Return on sales & $\begin{array}{l}0.032 \\
(200)\end{array}$ & $\begin{array}{l}0.037 \\
(206)\end{array}$ & $\begin{array}{l}0.038 \\
(269)\end{array}$ & 0.94 & 0.392 \\
\hline Continuous innovation activities & $\begin{array}{l}0.581 \\
(322)\end{array}$ & $\begin{array}{l}0.587 \\
(346)\end{array}$ & $\begin{array}{l}0.512 \\
(459)\end{array}$ & 3.69 & 0.025 \\
\hline Financial distress & $\begin{array}{l}0.304 \\
(322)\end{array}$ & $\begin{array}{l}0.306 \\
(346)\end{array}$ & $\begin{array}{l}0.285 \\
(459)\end{array}$ & 4.21 & 0.015 \\
\hline$\%$ trade credits paid late & $\begin{array}{l}15.21 \\
(259)\end{array}$ & $\begin{array}{l}11.65 \\
(246)\end{array}$ & $\begin{array}{l}11.01 \\
(326)\end{array}$ & 5.95 & 0.003 \\
\hline $\begin{array}{l}\% \text { trade credits with cash } \\
\text { discounts taken }\end{array}$ & $\begin{array}{l}60.95 \\
(241)\end{array}$ & $\begin{array}{l}63.38 \\
(225)\end{array}$ & $\begin{array}{l}63.50 \\
(288)\end{array}$ & 1.65 & 0.192 \\
\hline Firm size (employees) & $\begin{array}{l}67.95 \\
(322)\end{array}$ & $\begin{array}{l}34.06 \\
(346)\end{array}$ & $\begin{array}{l}22.70 \\
(459)\end{array}$ & 23.24 & 0.000 \\
\hline Firm age & $\begin{array}{l}20.00 \\
(322)\end{array}$ & $\begin{array}{l}16.69 \\
(346)\end{array}$ & $\begin{array}{l}14.43 \\
(459)\end{array}$ & 4.83 & 0.008 \\
\hline
\end{tabular}

Note: Borrowing firms only. Number of observations in parentheses. The F-statistic tests the equality of the mean values.

to maintain exclusive or highly concentrated relationships with financial institutions.

\subsection{Collateral requirements}

In order to reduce credit risk, a bank may demand collateral or some form of guarantee from the lender. Collateral may also help to classify risk groups more precisely (Bester, 1985). Availability of credit may be seriously restricted by the degree to which the firm can present assets to the bank which are acceptable as collateral. Collateral requirements and interest rates may be determined in a complex bargaining process on which we have virtually no data. To simplify the analysis, we will assume that collateral and interest rate conditions are determined in a sequential procedure, with the collateral decision preceding the determination of interest rates. A simultaneous setting of both parameters would be interesting, but it is not clear at this point what the exclusion restrictions in the system of simultaneous equations would be.

As our dependent variable for this analysis we define a binary dummy variable indicating whether any form of collateral or guarantee was necessary to obtain the line of credit. We do not distinguish here between different forms of collateral and/or guarantees while Berger and Udell (1995) present a study in which various types of collateral are included among the right-hand side 
variables in a probit equation. ${ }^{14}$ However, their results do not indicate that taking these variables into account affects conclusions in a major way.

We model the probability that the firm's most important line of credit had to be collateralized as a function of credit line volume, firm characteristics, variables describing the lending relationship, various owner and management characteristics, and control variables for the firm's geographic location and industry. Extending the specification used by Berger and Udell, we include the volume of the line of credit as an independent variable. The effect of lending relationships is captured in three variables: the duration of the lending relationship, the total number of institutions from which the firm borrows, and a dummy variable indicating whether the respondent at the firm characterizes the bank-firm relationship as one of mutual trust.

Based on the various theoretical rationales, our general expectations regarding the signs of the probit coefficients are as follows. First, ceteris paribus the bank will be more inclined to demand collateral as the volume of the line of credit increases. It is equally plausible to us that larger firms with greater bargaining power will be relatively more successful than smaller firms in evading these collateral demands. Firm age, as an indicator of the firm's observable reputation, is also likely to be negatively correlated with collateral requirements. The distress variable ought to carry positive coefficients since banks are likely to step up collateral demands in the face of a financial crisis.

As to the relationship variables, we follow Berger and Udell in hypothesizing that an increase in the duration of the lending relationship will lower collateral requirements. We also assume that mutual trust between firm and bank will yield the same effect. Conversely, if the number of lenders is relatively high, then any lender (and be it the most important one) will be confronted with a less transparent situation regarding its access to the firm's non-collateralized assets in the case of bankruptcy. Hence, collateral requirements should increase. We also expect that firms in East Germany face a more stringent collateral regime than their West German counterparts. This difference is likely to reflect the comparatively high risk of bankruptcy in the East German regions which still suffer from relatively high unemployment and - by 1997 - comparatively slow growth.

The results from our probit specifications are summarized in Table 6 . We introduce the exogenous variables in groups in order to observe how the correlation between some of them affects the results. Starting with a model that does not include relationship variables in column (1), we find the following pattern: the propensity of banks to (successfully) demand collateral increases with the volume of the credit line, but it decreases with firm age and firm size.

\footnotetext{
${ }^{14}$ As Berger and Udell note, these variables may be endogenously determined with the righthand side binary variable. While we have access to detailed information on types of collateral, we have not used them yet in our analysis.
} 
The distress indicator has considerable explanatory power. Firms that were in financial distress at some point during the five years prior to the survey are considerably more likely (by $15 \%$ at the sample mean) to pledge collateral for their L/Cs. Moreover, demanding collateral appears to be considerably more common in the construction and trade industries, and in East Germany. The management and owner characteristics are largely insignificant, as are most of the firm characteristics. 15

In columns (2) and (3), we also include the relationship variables among the regressors. In column (2) we exclude the trust variable, while it is included in column (3). In the latter specification, all of the relationship variables turn out to be significant: the logarithm of the duration of the lending relationship, the number of different institutions the firm borrows from (number of lenders), and the dummy variable indicating whether the respondent perceives the relationship between bank and firm to be characterized by mutual trust. The coefficient signs are consistent with our expectations. Longer-lasting lending relationships profit from reduced collateral requirements. Firms which engage in more lending relationships face more severe collateral requirements. The trust variable also carries the expected negative sign. Since $\ln$ (duration) and $\ln ($ age) are highly correlated $(\rho=0.692)$, it is not too surprising that the coefficient of the age variable drops from $-0.146(0.063)$ in column (1) to $-0.076(0.071)$ in column (3). Not surprisingly, the joint test of significance for both variables delivers a relatively strong result $\left(\chi^{2}=10.25, p<0.01\right)$ in column (3). However, greater explanatory power in the collateral equation seems to lie with the duration of the lending relationship rather than the firm's age. Exclusion of the trust variable has virtually no effect on the coefficients in column (3). The trust variable appears to capture information that is orthogonal, i.e. not contained in the other explanatory variables. While we do not have information on what determines the evolution of trust in bank-firm relationships, it seems clear that there is more to it than simply time passing by (i.e., duration) or the extent of competition (number of lenders).

One possible criticism regarding these specifications is the lack of balance sheet indicators which may - in principle - be observable to the bank. However, one should point out that German SMEs are typically less forthcoming with such information than (for example) small US firms. This is also reflected in the fact that we obtain data on interest rates and financing conditions more easily in our survey data than balance sheet information. In column (4), we use two balance sheet indicators as explanatory variables. Since we do not have full access to all of these at this point, the number of observations drops drastically by about 50\% (from 994 to 465 observations) and the standard errors in the

\footnotetext{
${ }^{15}$ The dummy variable for family-owned enterprises and for firms in the legal form of $\mathrm{KG}, \mathrm{OHG}$ or BGB are significant at the $10 \%$ level, but we do not discuss their impact here.
} 


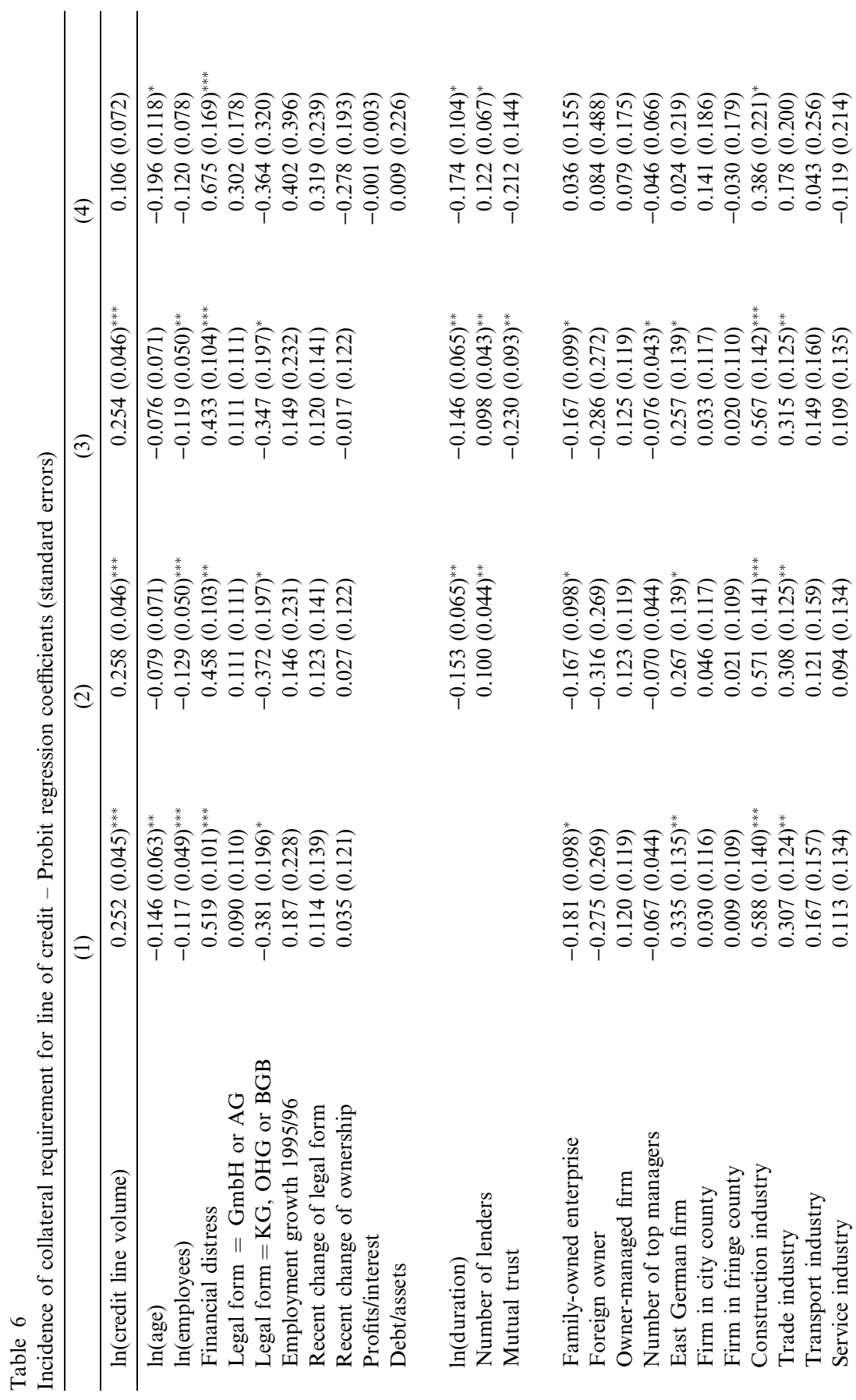




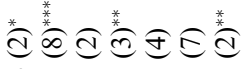

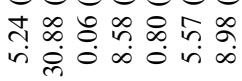

ॠั ते

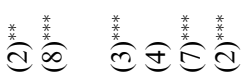
ㄴำ ๆ

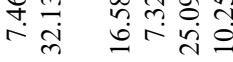

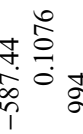

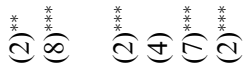

는

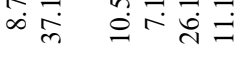

च

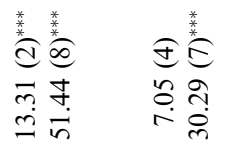

命

홍

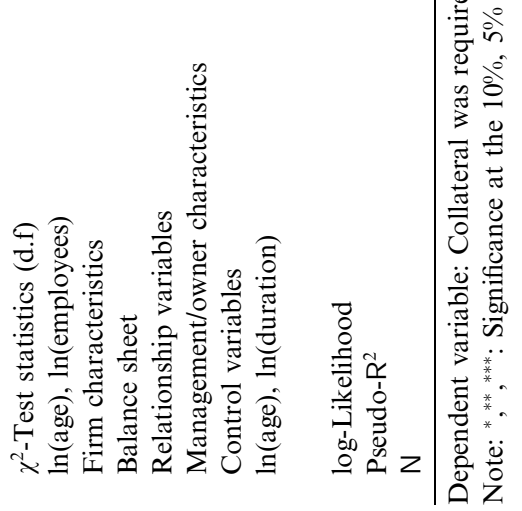


regression increase. The inclusion of the balance sheet variables affects most drastically the coefficients of the credit volume variable and firm size, although they remain jointly significant at the $2 \%$ level. The relationship variables that were significant in column (3) maintain their size, but their standard error increases by a factor of about 1.5 (which is roughly what one expects if the sample is reduced by slightly more than $50 \%$ ). The joint test on the two balance sheet variables is far from producing a significant test statistic, while the variables which proved significant in column (3) mostly remain significant at the $1 \%$ level. ${ }^{16} \mathrm{We}$ conclude that the lack of precision in this specification is due to the reduction in the number of observations, and not due to the inclusion of balance sheet indicators.

In specifications not reported here, we also included interaction terms between the distress variable and all relationship variables. The joint test of significance for the interaction terms would be a direct test of the hypothesis by Fischer (1990) that firms with close lending relationships should fare better in times of distress. However, the test statistic is not significant at any accepted level $\left(\chi^{2}(3)=0.33\right)$. Thus, there is no evidence here that the house bank model according to Fischer (1990) has any explanatory power. Lending relationships matter for collateral requirements - but they do not appear to be particularly relevant in times of distress. Since this extension does not lead to further insights, we maintain the results in column (3) as our preferred specification.

\subsection{Line of credit interest rates}

We now turn to the question of the cost of credit to firms. Again, we concentrate on lines of credit, since this type of credit should be more revealing than, say, mortgages (see Berger and Udell, 1995). In Fig. 1, we plot kernel density estimates of the distribution of 1997 interest rates on lines of credit for three subgroups in our sample: established West German firms (older than 10 years), young West German firms (up to 10 years of age), and East German firms. The latter two subsamples are roughly comparable in terms of their age and size distributions. The estimated density functions are striking: first, there is considerable variation of interest rates within each of the groups, and second, the differences between the samples are rather large. East German firms (which are almost by definition young and relatively small) face considerably higher interest rates than their young West German counterparts. The group of established firms faces the most favorable conditions. ${ }^{17}$

\footnotetext{
${ }^{16}$ The balance sheet variables become partly significant if we drop the financial distress variable, but they are statistically irrelevant once the distress dummy is included.

${ }^{17}$ These non-parametric distributions have a drawback at this point, since we do not take the sampling weights into account. However, the multivariate analysis below shows that the East-West differences are not just a consequence of differences in the observable determinants of interest rates.
} 


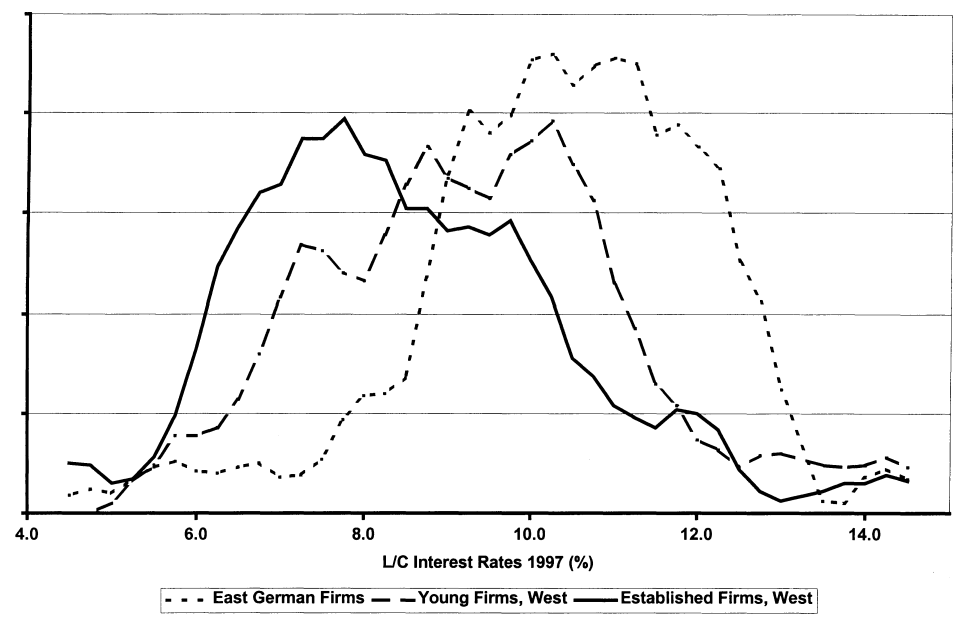

Fig. 1.

The results of an OLS regression of interest rates on various sets of explanatory variables are contained in Table 7. Interest on L/Cs is typically on a fixed-term basis in Germany, but price conditions may be renegotiated within relatively short time periods (such as three months). The German survey asked firms for their L/C interest rates as of 1 January 1997. By concentrating on a single reference point, we avoid potentially difficult issues such as correction for underlying prime rates etc. Hence, we take as our dependent variable the interest rate itself while Berger and Udell (1995) and Petersen and Rajan (1994) either consider the difference between interest and the prime rate or include the prime rate and terms of the $\mathrm{L} / \mathrm{C}$ among the right-hand side variables.

Again, we proceed sequentially in order to observe how coefficients react to the inclusion of further determinants. Note that the sample is slightly smaller than in the collateral requirement specification, since some firms were reluctant to give information about the interest rates they face. For the sake of brevity, we turn immediately to column (3) where all relationship characteristics have been included. The dominant firm characteristic determining interest rates appears to be the firm's size with a coefficient of -0.40 (standard error 0.061 ). Financial distress is again a significant determinant of credit conditions: firms which have encountered a financial crisis face interest rates that are on average 0.36 percentage points above those of other firms. The most notable offset in interest rates applies to East German firms. Ceteris paribus, their interest rates are about 0.92 percentage points higher than comparable West German firms. Another interesting effect becomes apparent in the city dummy variable. Firms in city counties will on average face higher interest rates, although banking competition is likely to be higher in densely populated cities than in fringe or rural counties. This result may be consistent with US patterns described in 


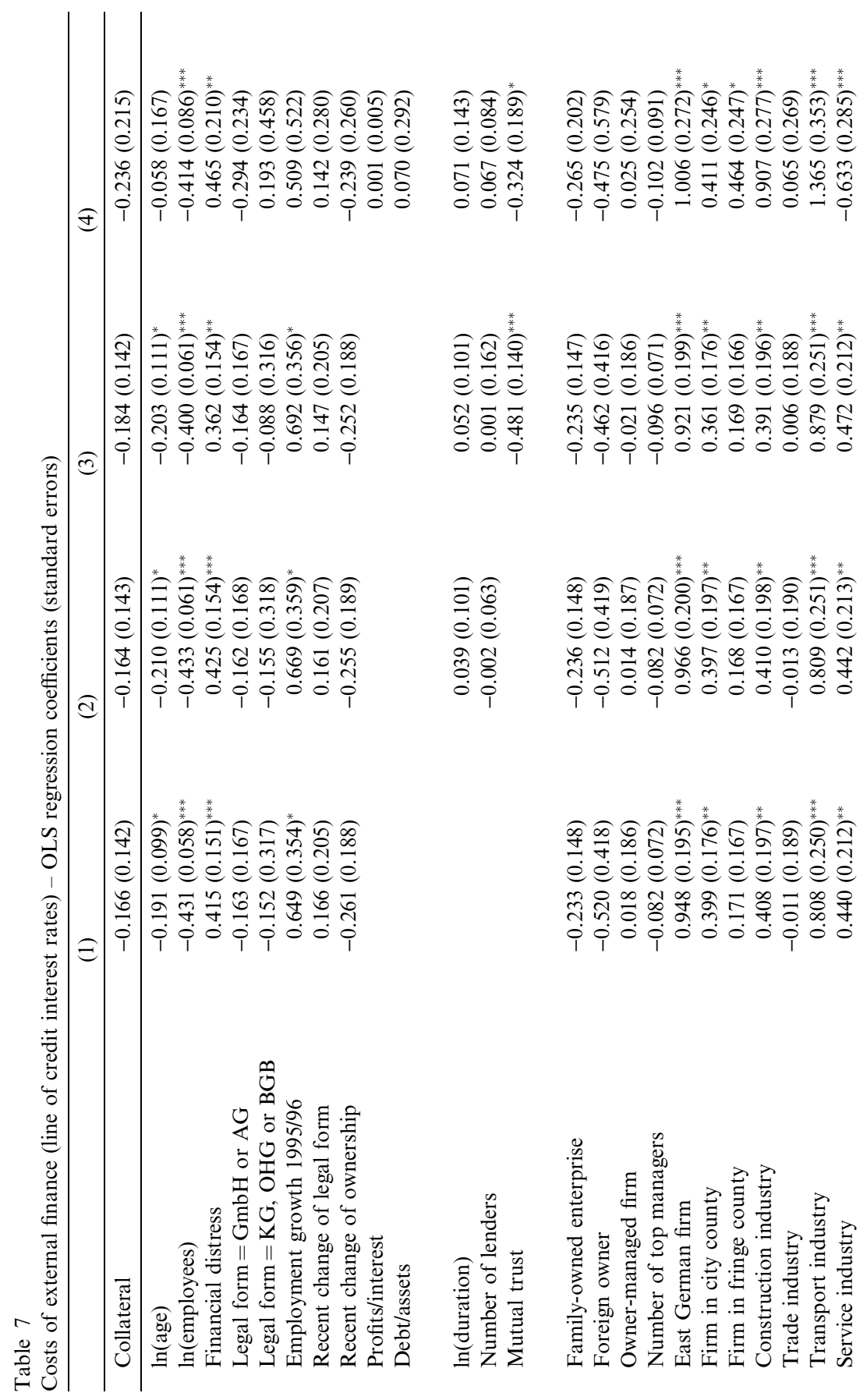



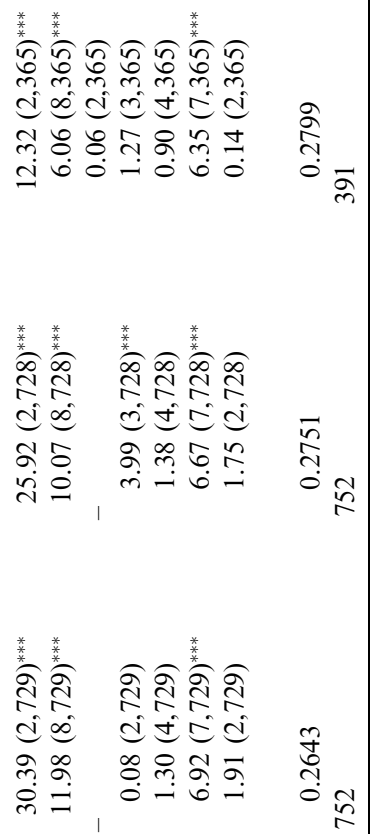

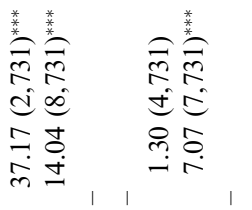

$$
\text { ते }
$$$$
\frac{\pi}{n} \sqrt{n}
$$$$
\text { 苞 }
$$

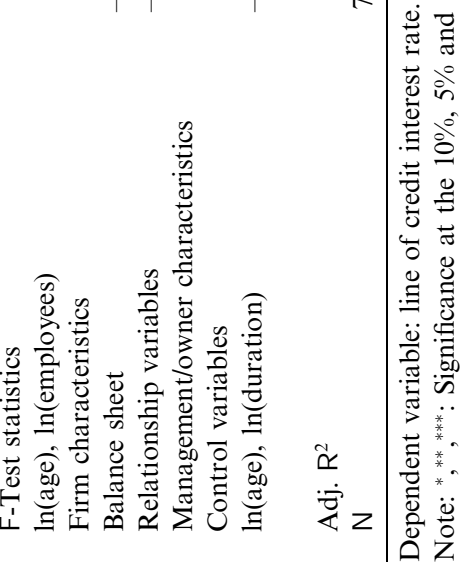


Petersen and Rajan (1995). They develop an explicit measure of bank concentration and find that in more concentrated markets, the availability of external finance increases.

Relative to the base category of manufacturing firms, firms in construction, transportation and services are required to pay relatively high interest rates. These differences may reflect underlying differentials in insolvency rates or diverging opportunities for pledging collateral. Somewhat surprisingly and contrary to the evidence in Petersen/Rajan, fast-growing firms (in terms of employment growth) face higher interest rates than those with more modest revenue growth. Taken at face value, this result may suggest that surging demand for capital will lead to an increase in the price of debt. Interestingly, this result may be consistent with the conclusion by Winker (1996) that fastgrowing German firms are more likely to encounter financing constraints.

One can see that firm age appears to have a significant negative effect on interest rates while the duration variable turns out to be insignificant. We find it remarkable that the coefficient estimate we obtain for the age variable in this regression $(-0.203$ with standard error 0.111$)$ is virtually identical to the estimate Petersen and Rajan (1994) present (Table IV, column (2): -0.227 with standard error 0.078). As in their study, price conditions for L/Cs in Germany are apparently not affected by the duration of the lending relationship. Thus, our results are not consistent with the estimates generated by Berger and Udell (1995) which should - in principle - be comparable since the dependent variable is in both cases the L/C interest rate. Contrary to the Petersen/Rajan results, however, we find no evidence in this specification that the number of lenders affects interest rates. ${ }^{18}$ In the respective US results, the number of banks from which the firm borrows has a strong positive effect on interest rates. An additional source of external finance raises interest rates by about 31 basis points in the Petersen/Rajan study, while there is no such effect in Germany. The only relationship variable that turns out to be highly significant is the indicator of trust which carries the expected sign and accounts for a 0.48 percentage point reduction in interest. Again, one is tempted to ask whether the trust variable masks the effects of other relationship variables, since it is likely to be itself a function of the concentration of borrowing and the duration of the relationship. However, dropping this variable in column (2) does not lead to any major changes of the results. Thus, price conditions for lines of credit in Germany are apparently not affected by the duration of the lending relationship or by the number of institutions from which the firm borrows. Trust between the borrowing and the lending organization may nonetheless contribute to a significant reduction of the costs of external finance. The finding that the

\footnotetext{
18 This explanatory variable is not used in the Berger/Udell study. In our study, including the Herfindahl index of borrowing concentration did not yield significant results, either.
} 
duration of the bank-firm relationship does not affect $\mathrm{L} / \mathrm{C}$ interest rates is not inconsistent with our first hypothesis (H1). As the bank learns more about a particular firm, interest rate conditions should improve at least for high-quality firms. We do not observe such an effect, but this result may be due to imperfect measures of the firm's quality.

The introduction of balance sheet indicators in this regression in column (4) mostly affects the coefficients of the trust variable and of the age variable. But as in the collateral equation, the balance sheet indicators taken jointly are far from reaching any conventional confidence level $(F(2,365)=0.06, p>0.1)$. Neither does the inclusion of relationship variables interacted with the distress dummy variable yield significant results (not reported in Table 4). The test statistic (degrees of freedom) for the joint test of these variables is $F(3,725)=0.33(p>0.1)$. Given these results, we maintain column 3 as our preferred specification.

\subsection{The availability of external finance}

We follow Petersen and Rajan (1994) by using a measure of trade credit usage in order to infer the availability of external finance. ${ }^{19}$ The use of the indicators follows the logic that financing constraints should be indirectly observable when a firm makes use of a particularly expensive form of credit, i.e. at interest rates far in excess of "normal" rates charged by banks. In Table 8 , we use fast payment discounts taken as a share of fast payment discounts offered to the firm as our dependent variable. The penalty for not taking fast payment discounts is relatively high and given by the implicit interest rate of fast payment discount rules: in Germany a $2 \%$ fast payment discount is typically granted if payment is made within two weeks, but there may be considerable differences across industries.

Turning directly to the preferred specification in column (3), we find that firm age affects credit availability significantly while the duration of the lending relationship is not a relevant regressor. Firms in financial distress tend to take fast payment discounts considerably less often than financially sound firms. With the exception of the number of lenders which exerts a negative impact on credit availability, none of the remaining variables in the first panel of Table 8 turn out to be significant. However, we obtain a highly significant negative effect for East German firms, indicating that these firms are less likely than

\footnotetext{
${ }^{19}$ Petersen and Rajan (1994) actually use two indicators: the share of trade credit paid late and fast payment discounts actually taken as a share of fast payment discounts offered to the firm. We only use the latter variable, since it is more appealing to us in purely theoretical terms. Foregoing fast payment discounts carries a relatively precise price (the discount), while paying trade credit late will usually trigger a deterioration of trade credit conditions which is much harder to assess in cost terms.
} 


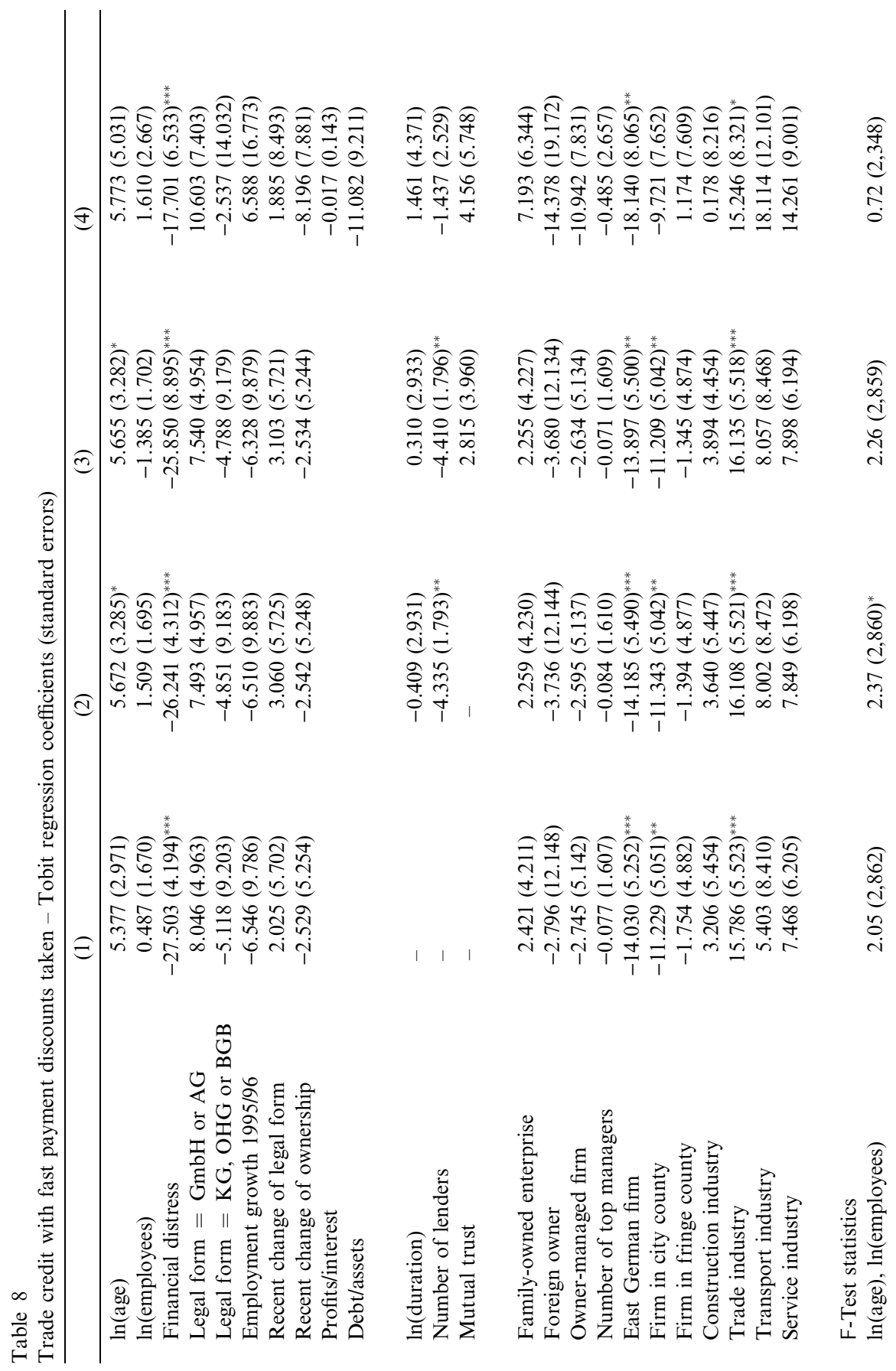




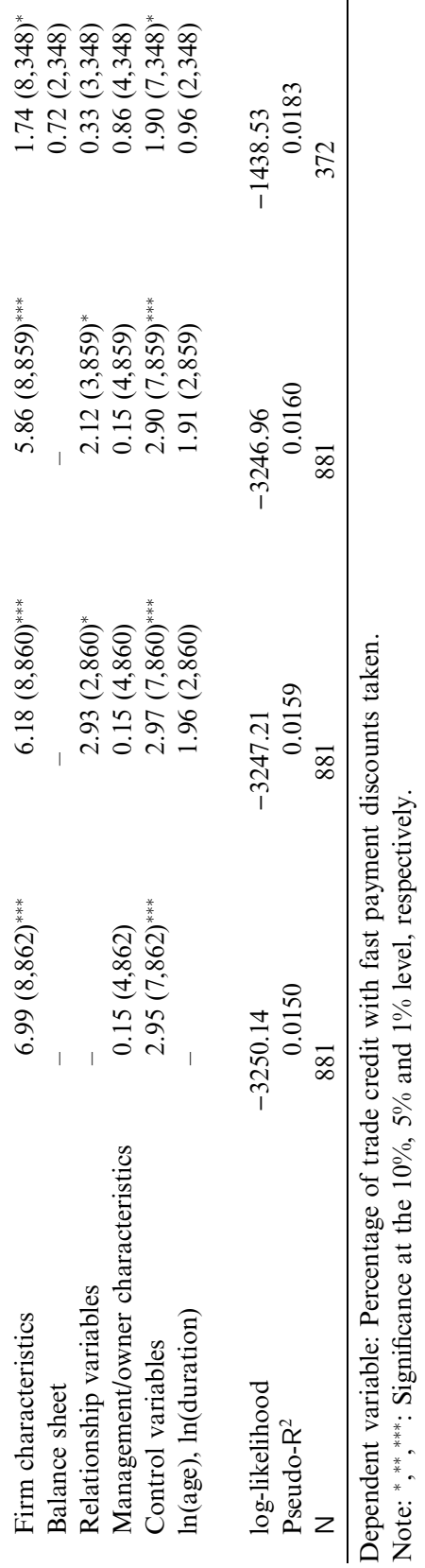


comparable West German enterprises to take fast payment discounts. Moreover, firms in city counties are less likely than firms in sparsely populated rural counties to take fast payment discounts. The balance sheet variables are again insignificant when the distress dummy variable is included in the regression.

The results from this regression are less satisfactory than those presented before. We see relatively low measures of fit (i.e., the pseudo-R-squared values) which may be due to noisy measurement. Despite this caveat, however, the results regarding the number of lenders, the firm's age and the control variables for firms in East Germany and in city counties are statistically significant and logically consistent with our previous estimates. In particular, these results indicate that firms with fewer lenders have to forego fast payment discounts less often than otherwise comparable firms with a more dispersed borrowing structure. Increasing exclusivity of borrowing appears to have a favorable impact on the availability of debt capital.

\section{Conclusions and further research}

With this paper, we have attempted to explore the nature of firm-bank relationships in Germany and their impact on the collateral requirements, cost, and availability of external finance for small and medium-sized enterprises. Towards this objective, we have employed a rich new dataset which has been collected for the purpose of this analysis. We find that in the SME segment of the German economy, lending is typically heavily concentrated on one or two financing institutions. Many firms (in particular smaller enterprises) maintain exclusive lending relationships, and typically one financial institution contributes at least two-thirds of the overall loan volume.

We find that loan volume increases the propensity of banks to demand collateral while firm size has a dampening effect. If the firm has been in financial distress prior to our base year 1997, the likelihood of collateral requirements increases sharply. The duration of the lending relationship is a significant regressor in its own right, and the number of financial institutions from which the firm borrows has a positive impact on collateral requirements. If respondents indicate that there is mutual trust between bank and firm, collateral requirements are significantly lower, but this relationship could be spurious due to simultaneity problems. However, our estimation results are virtually unchanged if we exclude this variable.

As to the cost of external finance (measured by the L/C interest rate), we find the expected dependence of interest rates on the size of the firm and the firm's age, but none on the duration of the lending relationship. Moreover, financial distress appears to lead to a considerable increase in interest rates of about 0.36 percentage points. Controlling for observable differences between firms, we find that East German firms pay about one percentage point more in $\mathrm{L} / \mathrm{C}$ interest 
rates. This may reflect the risk premium charged by banks in the depressed East German economy. Firms in city counties have to pay interest rates that are about 0.4 percentage points higher than firms in fringe and rural counties. This result appears to be consistent with estimates presented by Petersen and Rajan (1995) who argue that reduced competition among lenders will tend to increase the availability of debt finance. Mutual trust between bank and firm (as perceived by our respondents in the firms) appears to have a strong beneficial effect on interest rates and accounts for a differential of 0.48 percentage points.

In our test of credit availability we use the percentage of fast payment discounts actually taken as our endogenous variable. We find the expected positive age effect, a negative impact of financial distress, and a negative impact of the number of lending institutions. East German firms appear to be more finance-constrained than West German ones. Moreover, we find that firms in city counties are more likely to be constrained than firms in fringe and rural counties. This result is consistent with the positive interest differential for city county firms which became evident in the L/C interest equation. ${ }^{20}$

Taken together, these results suggest that long-lasting lending relationships and concentrated borrowing are desirable to firms. The data are not consistent with the Edwards/Fisher hypothesis that weaker firms seek to establish particularly close relationships, albeit at some cost. Ceteris paribus, firms with more concentrated borrowing and long-lasting bank relationships fare better than other enterprises in terms of collateral requirements, interest rates, and credit availability. The exact interpretation of the lending relationship variables is not trivial: these appear to affect collateral requirements and the availability of credit more strongly than its price. Some of these variables (e.g. the number of institutions from which the firm is borrowing) may be a function of the firm's financial status or quality. Thus, 'good' firms may tend to have longterm relationships with relatively few institutions, while bad ones have to engage in multiple relationships, since banks may not want to shoulder the risk of these engagements alone. We will attempt to sort out these rival hypotheses in further studies.

\section{Acknowledgements}

This paper was written while the first author was on leave from ZEW and Visiting Research Professor at the Berlin Centre for Social Sciences Research (WZB). The hospitality of WZB and its research support are gratefully ac-

\footnotetext{
${ }^{20}$ One should also note that the strong correlation between our distress variables and the trade credit indicators provides ample support for using observations on the firm's trade credit behavior in credit monitoring and rating activities.
} 
knowledged. The data used in this study were collected under a grant from the German Research Council (DFG), the Ministry of Economics (Bundesministerium für Wirtschaft), and the ZEW. None of the views expressed in this paper should be ascribed to either of the funding organizations. We acknowledge helpful suggestions from seminar audiences in Heidelberg, Frankfurt, Berlin and Vienna, and in particular from Helmut Bester, Wolfgang Clemenz, Martin Hellwig, Jan Pieter Krahnen, Winfried Pohlmeier, Konrad Stahl and Peter Winker. We are also thankful to several banking practitioners and firm executives for insightful comments. The usual disclaimer applies.

\section{Appendix A}

The data used in this paper originate from a recently concluded survey of 1509 German small and medium-sized enterprises (SMEs). The survey was motivated by the fact that detailed information on financing patterns of German SMEs is very scarce. Given that we sought relatively comprehensive data, a mailed survey was ruled out. Instead, we decided to conduct a relatively detailed person-to-person interview, employing the help of a large professional surveying institute. The interviews took place between July and October 1997. The construction of the sampling frame was based on data records obtained from Creditreform, Germany's largest credit-rating agency.

\section{A.1. Questionnaire design}

The design of the questionnaire is very similar to the one used by the US Small Business Administration to conduct the National Survey of Small Business Finances. ${ }^{21}$ The German questionnaire consists of a screening questionnaire and a main questionnaire. The screening questions seek to ensure that only independent ${ }^{22}$ private profit-seeking enterprises with no more than 500 employees (on average in 1996) are actually interviewed.

In the first part of the main questionnaire, the interviewers collect general information about firm characteristics. These include location of headquarter, number of employees, industry classification, and legal form. Furthermore, this

\footnotetext{
${ }^{21}$ For details on this survey, see Petersen and Rajan (1994) pp. 6-7 and the references cited therein. We obtained the questionnaire from the S.B.A. and adopted a number of particularly relevant questions to the German context. We have attempted to keep questions comparable in order to allow for future US-German comparisons at the firm level. The questionnaire is available on request from the authors.

${ }^{22} \mathrm{~A}$ firm is taken to be independent if no more than $50 \%$ of the shares are held by another company.
} 
part of the questionnaire includes a section on socio-demographic information about the firm's managers and owners.

The second part collects information about the firm's investment and innovation activities. The section referring to innovation activities is divided in two blocks taking into account the differences in innovation activities between non-service and service firms. Both the investment activities section and the innovation activities section contain a thought experiment which seeks to distinguish firms that are debt-rationed from those which are not.

The third part of the questionnaire sheds some light on the firm's relationships to financial institutions and its financing patterns. The first section contains only questions concerning the firm's experience with state subsidies, followed by questions dealing with trade credit (Section 2) and qualitative questions about relationships to financial institutions (Sections 3-5). Section 5 begins with questions about the number of different financial relationships, the fractions borrowed from the five most important institutions and finally focuses on relationship characteristics concerning the most important financing institution. We then seek information in Sections 6-8 on the firm's experience with credit applications, on sources of external funding, and detailed information about the most important loans. These sections also yield information whether a change in the firm's financial relationships has occurred within the last five years and why it has occurred. The detailed credit information in Section 7 contains questions on borrowing conditions such as interest rate, loan volume, maturity, and collateralization. The questionnaire closes with a section collecting data from the last balance sheet and profit and loss accounts.

\section{A.2. Sample design}

As mentioned in the Introduction, we expected a high degree of reluctance to take part in an interview. In order to allow for an ex post evaluation of selectivity effects, it was therefore important to have available quantitative information on non-respondents. Therefore, all of the addresses were basically taken from the database of Creditreform, Germany' largest credit-rating firm. Prior to sampling, we excluded the following firms from the databases employing the VVC information:

firms having no usable address,

firms which have ceased to exist or had declared bankruptcy,

dependent firms, i.e. firms belonging to more than $50 \%$ to other firms or organizations,

firms in the legal form "Freie Berufe" (independent professionals), "Arbeitsgemeinschaft" or "eingetragene Genossenschaft" (co-operative) and "eingetragener Verein" (association),

firms with more than 500 employees,

firms not belonging to the following industries (two-digit WZ93 code): 15, 
$16,17,18,19,20,21,22,23,24,25,26,27,28,29,30,31,32,33,34,35,36$, $37,45,50,51,52,60,61,62,63,64,72,73,74$.

Additionally, we excluded the following East German firms:

firms founded prior to the fall of the Iron Curtain,

firms belonging partly or totally to the "Treuhandgesellschaft" (the holding company set up to privatize former East German cooperatives),

firms belonging totally or partly to West German or foreign parent firms.

In the case of young West German firms, we omitted records with more than 250 employees, since these will in all likelihood not originate from independent start-up firms.

After these exclusions, we produced a random sample stratified by industry and firm size in three steps. First, a dataset of 143 firms in the area of Munich was created for pretest purposes. This pretest was conducted for 15 firms in order to improve the questionnaire design. Second, a dataset of established West German firms was drawn, which finally included addresses from 5051 firms. A third sample of young West German firms (founded after 1989) consisted of 1920 observations. Finally, a fourth sample of East German firms contained 2585 addresses. A total of 9699 addresses was transferred to the survey institute. Not all of the addresses were actually used in the process of contacting firms. In 4366 cases, the target individual of the study (the Geschäftsführer or Prokurist in charge of financial affairs of the firm) was actually reached via telephone. We consider this group the relevant gross sample. In 1181 of these cases, the individuals contacted did not grant an interview, since they considered the time requirement (60-90 min) as too severe. In 1497 cases, they pointed to the topic of our survey as the main reason for not complying with our interview request. 165 candidates gave other reasons for not participating in the study, and 14 interviews actually took place, but did not produce usable information. Thus, 1509 interviews were actually conducted.

When this article was being written inconsistencies in 110 questionnaires required us to restrict the sample to 1399 observations.

\section{References}

Aghion, P., Bolton, P., 1992. An incomplete contract approach to financial contracting. Review of Economic Studies 59, 473-494.

Allen, F., Gale, D., 1995. A welfare comparison of intermediaries and financial markets in Germany and the US. European Economic Review 39, 179-209.

Bhattacharya, S., Thakor, A.V., 1993. Contemporary banking theory. Journal of Financial Intermediation 3, 2-50.

Berger, A.N., Udell, G., 1995. Relationship lending and lines of credit in small firm finance. Journal of Business 68, 351-381.

Bester, H., 1985. American Economic Review Screening vs. rationing in credit markets with imperfect information $75,850-855$. 
Boot, A.W.A., Thakor, A.V., 1994. Moral hazard and secured lending in an infinitely repeated credit market game. International Economic Review 35, 899-920.

Corbett, J. and Jenkinson, T., 1994. The financing of industry, 1970-89: An international comparison. CEPR Discussion Paper No. 1512, Centre for Economic Policy Research (CEPR), London.

Drukarcyk, J. et al., 1985. Mobiliarsicherheiten, Arten, Verbreitung, Wirksamkeit. Bundesministerium der Justiz. Bonn.

Edwards, J., Fischer, K., 1994. Banks, Finance and Investment in Germany. Centre for Economic Policy Research, Cambridge.

Elliehausen, G.E., Wolken, J.D., 1993. The demand for trade credit: An investigation of motives for trade credit use by small businesses. Federal Reserve Bulletin, pp. 1-18.

Elsas, R., Henke, S., Machauer, A., Rott, R., Schenk, G., 1997. Empirische Untersuchung von Kreditengagements mittelstä ndischer Unternehmen - Samplingkonzeption und deskriptive Statistik. Working Paper, Center for Financial Studies, Frankfurt/Main.

Fischer, K., 1990. Hausbankbeziehungen als Instrument der Bindung zwischen Banken und Unternehmen. Dissertation Thesis, University of Bonn.

Gale, D., Hellwig, M., 1985. Incentive-compatible debt contracts: The one-period problem. Review of Economic Studies 52, 647-663.

Greenbaum, S.I., Kanatas, G., Venezia, I., 1989. Equilibrium loan pricing under the bank-client relationship. Journal of Banking and Finance 13, 221-235.

Harhoff, D., Stahl, K., Woywode, M., 1998. Growth and exit of West German firms - An empirical investigation on the impact of liability statutes. Journal of Industrial Economics, forthcoming.

Harhoff, D., 1998. Are there financing constraints for R\&D and investment in German manufacturing firms. Annales d'Économie et de Statistique, forthcoming.

Hesselmann, S., Stefan, U., 1990. Zerschlagung oder Sanierung von Unternehmen bei Insolvenz. Schriften zur Mittelstandsforschung des Instituts für Mittelstandsforschung, Bonn, Stuttgart.

Kaplan, S.N., Zingales, L., 1997. Do investment-cash flow sensitivities provide useful measures of financing constraints. Quarterly Journal of Economics CXII, 169-216.

Loveman, G., Sengenberger, W., 1991. The re-emergence of small-scale production: An international comparison. Small Business Economics 3, 1-38.

Mayer, C., 1988. New issues in corporate finance. European Economic Review 32, 1167-1188.

Mokerjee, D., Png, I., 1989. Optimal auditing, insurance and redistribution. Quarterly Journal of Economics CIV, 399-415.

Petersen, M.A., Rajan, R.G., 1994. The benefits of lending relationships: Evidence from small business data. Journal of Finance XLIX (1), 3-37.

Petersen, M.A., Rajan, R.G., 1995. The effect of credit market competition on lending relationships. Quarterly Journal of Economics CX, 405-443.

Rajan, R.G., 1992. Insiders and outsiders: The choice between informed and arm's-length debt. Journal of Finance XLVII (4), 1367-1400.

Schiantarelli, F., 1995. Financial constraints and investment: A critical review of methodological issues and international evidence. Boston College, Department of Economics, Working Paper No. 293 .

Schmidt-Mohr, U., 1997. Rationing versus collateralization in competitive and monopolistic credit markets with asymmetric information. European Economic Review 41, 1321-1342.

Sharpe, S.A., 1990. Asymmetric information, bank lending, and implicit contract: A stylized model of customer relationships. Journal of Finance 45, 1069-1087.

Stiglitz, J., Weiss, A., 1981. Credit rationing in markets with imperfect information. American Economic Review 71, 393-410.

Van Damme, E., 1994. Banking: A survey of recent microeconomic theory. Oxford Review of Economic Policy 10, 14-33.

Winker, P., 1996. Rationierung auf dem Markt für Unternehmenskredite in der BRD. Tübingen: Mohr. 